\title{
Ontogeny of Fibroblast Growth Factors in the Early Development of the Rat Endocrine Pancreas
}

\author{
EDITH ARANY AND DAVID J. HILL \\ Medical Research Council Group in Fetal and Neonatal Development, Lawson Research Institute, St. \\ Joseph's Health Centre, London, Ontario N6A 4V2, Canada [E.A., D.J.H.]; and Departments of \\ Physiology [D.J.H.], Medicine [E.A., D.J.H.] and Pediatrics [D.J.H.], University of Western Ontario, \\ London, Ontario N65 5A5, Canada [D.J.H.]
}

\begin{abstract}
Pancreatic islet ontogeny involves endocrine cell neogenesis from ductal epithelium and islet expansion by cell replication, balanced by apoptotic deletion of endocrine cells which, in rat, is pronounced in the neonate. Fibroblast growth factors (FGF) are involved in tissue morphogenesis, and we examined the distribution and ontogeny of several FGF within rat pancreas from late fetal life until weaning. Islet cell replication (immunohistochemistry for proliferating cell nuclear antigen) did not change, but a transient increase in ductal epithelial cell replication existed between postnatal days (pnd) 10 and 14. Immunoreactive FGF-1 was found mainly in $\alpha$ cells of islets, and FGF-2 immunoreactivity and mRNA throughout the islets, their distribution increasing with age. Both FGF-1 and -2 were also located in ductal epithelium, being maximally distributed at pnd 10-14, coincident with increased cell replication, and when mRNA transcripts encoding FGF-1 $(4.4 \mathrm{~kb})$ and FGF-2 $(7 \mathrm{~kb})$ were relatively
\end{abstract}

ABSTRACT

increased in pancreata. FGF-4 and -6 immunoreactivities were localized strongly within islets and ductal cells. In contrast, immunoreactive FGF-7 was associated with pancreatic mesenchyme and intra-and extraislet endothelial cells, and mRNA abundance was transiently increased between pnd 4 and 12, suggesting a role in the initiation of endocrine cell neogenesis. Exogenous FGF-7 was fivefold more potent than FGF-1 or -2 in stimulating DNA synthesis within isolated rat islets. Multiple FGF are expressed within defined compartments of developing pancreas and may contribute to endocrine cell neogenesis and islet function. (Pediatr Res 48: 389-403, 2000)

\section{Abbreviations}

FGF, fibroblast growth factor

PCNA, proliferating cell nuclear antigen

pnd, postnatal day
Insulin is a major developmental hormone in the embryo and fetus, and its absence due to gene ablation by homologous gene recombination in mouse results in severe growth retardation at birth (1). Similarly, gross pancreatic deficiency in the human infant, sometimes associated with abnormality in the gene structures of morphogenic transcription factors, causes intrauterine growth restriction, poor lean body mass, and a deficiency of adipose tissue $(2,3)$. Less extreme intrauterine growth retardation in both rat and man as a result of fetal malnutrition is accompanied by a reduced pancreatic $\beta$-cell mass and insulin content $(4,5)$. The implications of this may be long-lived because individuals have a pronounced increase in susceptibility to diseases such as type 2 diabetes, hypertension, and cardiac ischemia in later life (6). Understanding the locally acting signals that control the normal progression of pancreatic $\beta$-cell growth and maturation are therefore central to under-

Received July 2, 1999; accepted May 2, 2000.

Correspondence: Dr. Edith Arany, Lawson Research Institute, St. Joseph's Health Centre, 268 Grosvenor Street, London, Ontario, NA6 4V2, Canada. standing the mechanisms of fetal "programming" of adult disease.

The FGF family of 19 related peptides transmit mitogenic, angiogenic, and morphogenetic signals to a wide range of developing fetal and neonatal cell types via four high-affinity receptors, designated FGFR1 to FGFR4 (7). However, little is understood of their contributions to the development of the endocrine pancreas. FGFR are normally absent from isolated adult islets (8), but in both the rat and midtrimester human fetus, FGF-2 (basic FGF) and FGFR1 have been localized to the pancreatic ductal epithelial cells and to small developing islets $(9,10)$. Additionally, FGFR4 is highly expressed in a model of fetal rat islet development in vitro $(11,12)$.

Endocrine cells are thought to develop from pancreatic duct epithelial cells during embryogenesis and undergo a lineage progression and replication. Initially, they exist as individual cells or small clusters close to the pancreatic ducts and only form mature islets, with outer $\alpha$ cells and $\delta$ cells and an inner mass of $\beta$ cells, a few days before birth. The growth and cytodifferentiation of the pancreas depends on mesenchymal- 

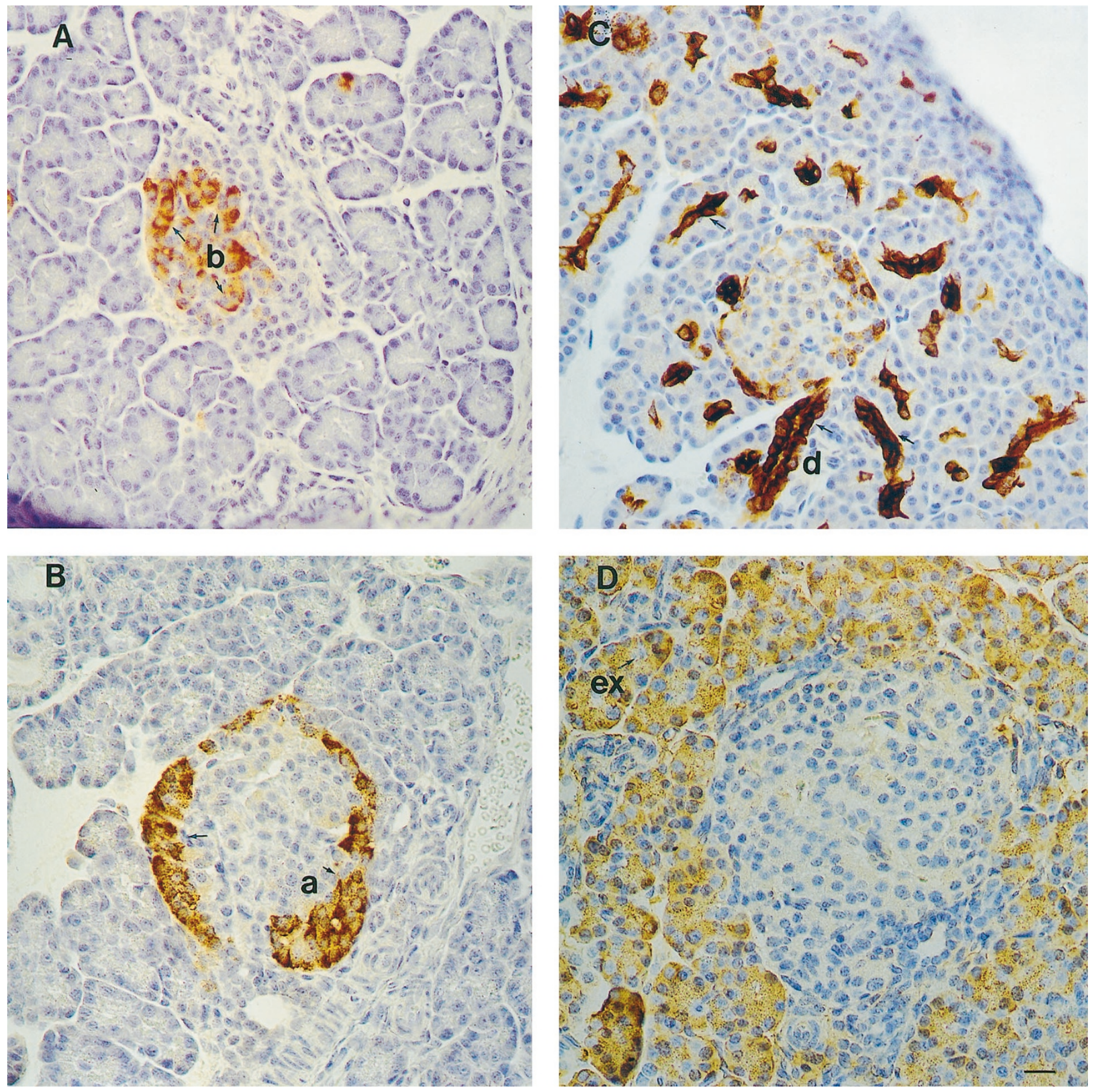

Figure 1. Immunohistochemical localization of insulin $(A)$, glucagon $(B)$, cytokeratin $(C)$, and amylase $(D)$ to distinguish endocrine cell components of the islets, ductal epithelial tissues, and exocrine cells in rat pancreas at pnd 12-14. Arrows show the cellular distribution of staining to $\alpha$ cells $(a), \beta$ cells $(b)$, ductal epithelium $(d)$, or exocrine cells $(e x)$. Counterstaining of tissues is with Carazzi's hematoxylin. Magnification bar $=10 \mu \mathrm{m}$.

epithelial interactions. Pancreatic mesenchyme accumulates around the dorsal gut epithelium and induces pancreatic bud formation and branching. Endocrine cells develop from the pancreatic duct epithelial cells and undergo a lineage progression and replication that has been modeled by Teitelman (13, 14). The earliest endocrine cells in the lineage express glucagon alone and form $\alpha$ cells. Insulin-expressing $\beta$ cells develop from cells coexpressing glucagon, whereas somatostatinexpressing D cells develop from cells coexpressing insulin. These lineages are likely to be controlled by epigenetic signals including transcription factors and the effects of peptide growth factors, such as the FGF, within the total environment of the pancreatic rudiment.

Neogenesis of islets is rapid in the fetus and continues through neonatal life in the rat, but ceases shortly after weaning (15). This derives not only from $\beta$-cell replication but from the recruitment and maturation of undifferentiated $\beta$-cell precursors (16). Conversely, the rate of mitosis in adult pancreatic $\beta$ cells is normally low ( $3 \%$ replication rate of $\beta$ cells per day) (17). A transient wave of apoptosis occurs in neonatal rat islets 
Table 1. Percentage of islet cells (I) or ductal epithelial cells (D) demonstrating immunoreactivity for FGF-1, -2, -4, or -6, insulin, glucagon, or PCNA between 21 d gestation and pnd 22

\begin{tabular}{|c|c|c|c|c|c|c|c|c|}
\hline $\begin{array}{c}\text { Age } \\
\text { (days) }\end{array}$ & & FGF-1 & FGF-2 & FGF-4 & FGF-6 & Insulin & Glucagon & PCNA \\
\hline \multirow[t]{2}{*}{ Fetal 21} & I & $7.5 \pm 2.9$ & $14.5 \pm 1.3$ & $48.2 \pm 5.2$ & $35.3 \pm 2.8$ & $78.1 \pm 0.5$ & $12.2 \pm 0.3$ & $3.5 \pm 0.6$ \\
\hline & $\mathrm{D}$ & $42.4 \pm 5.5$ & $76.1 \pm 9.3$ & $12.3 \pm 3.8$ & $85.3 \pm 11.4$ & - & - & $7.2 \pm 1.1$ \\
\hline pnd 6 & $\mathrm{D}$ & $52.1 \pm 6.2$ & $50.8 \pm 7.2$ & $10.3 \pm 0.5$ & $80.6 \pm 9.2$ & - & - & $8.7 \pm 2.5$ \\
\hline \multirow[t]{2}{*}{ pnd 10} & I & $12.6 \pm 1.4$ & $28.8 \pm 4.8^{*}$ & $55.3 \pm 6.4$ & $48.3 \pm 4.5$ & $80.2 \pm 1.1$ & $13.4 \pm 0.8$ & $3.5 \pm 0.5$ \\
\hline & $\mathrm{D}$ & $55.3 \pm 6.3$ & $53.2 \pm 6.0$ & $8.8 \pm 4.2$ & $78.1 \pm 3.8$ & - & - & $11.2 \pm 2.6^{*}$ \\
\hline \multirow[t]{2}{*}{ pnd 14} & I & $18.9 \pm 2.1^{*}$ & $28.1 \pm 3.5 \dagger$ & $61.4 \pm 3.4$ & $63.1 \pm 5.7$ & $72.5 \pm 0.9$ & $16.5 \pm 1.1$ & $5.3 \pm 0.7$ \\
\hline & $\mathrm{D}$ & $71.0 \pm 5.7^{*}$ & $73.4 \pm 8.1$ & $9.9 \pm 4.2$ & $82.8 \pm 12.3$ & - & - & $12.5 \pm 1.9 *$ \\
\hline \multirow[t]{2}{*}{ pnd 22} & I & $25.6 \pm 2.2 \dagger$ & $34.4 \pm 3.9 \dagger$ & $58.2 \pm 4.6$ & $39.9 \pm 4.2$ & $72.8 \pm 0.2$ & $22.1 \pm 0.6$ & $3.1 \pm 0.7$ \\
\hline & $\mathrm{D}$ & $32.9 \pm 4.4$ & $36.2 \pm 4.0$ & $5.1 \pm 2.2$ & $52.0 \pm 8.7$ & - & - & $9.0 \pm 3.4$ \\
\hline
\end{tabular}

Figures represent mean values $\pm \operatorname{SEM}(n=5$ animals $)$.

$* p<0.05, \dagger p<0.01$ vs fetal d 21 .
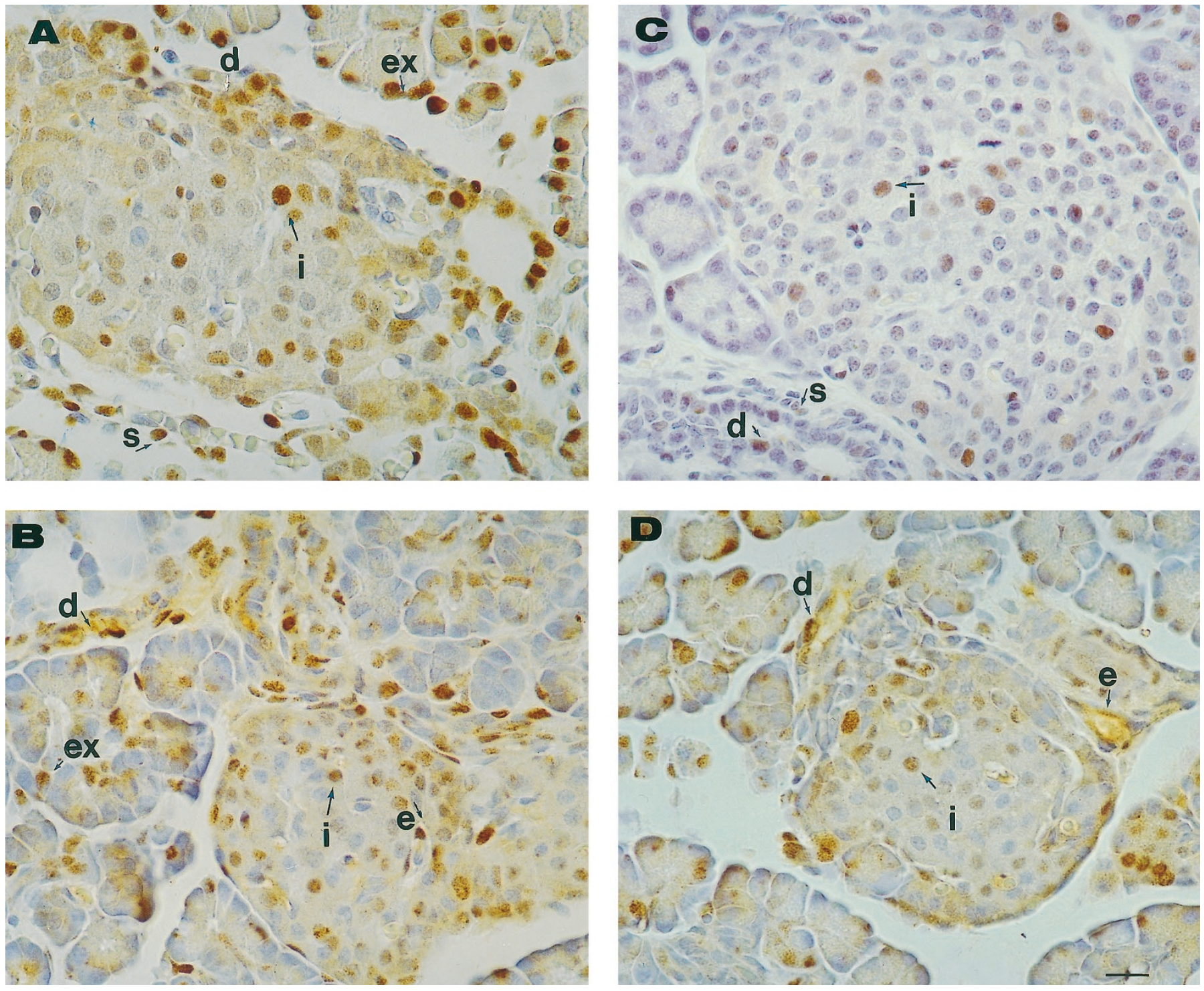

Figure 2. Immunohistochemical localization of PCNA in rat pancreas at fetal d $21(A)$, and pnd $10(B), 14(C)$, or $22(D)$. Arrows show the cellular distribution of staining to islets $(i)$, endothelial cells $(e)$, ductal epithelium $(d)$, exocrine cells $(e x)$, or stroma $(s)$. Magnification bar $=10 \mu \mathrm{m}$. 
between 1 and 2 wk of age $(18,19)$, and increased numbers of insulin-positive cells are seen near to the ductal epithelia after $12 \mathrm{~d}$, suggesting the generation of new islets to maintain $\beta$-cell mass. This ontogeny may provide a $\beta$-cell population suited to metabolic control in later adult life.

To better understand the contribution of various FGF to islet cell neogenesis and replication we have examined in this study their ontogeny and distribution in the developing rat pancreas between late fetal life and weaning, and their mitogenic actions on isolated islets.

\section{MATERIALS AND METHODS}

Animals. Pregnant Wistar rats (Charles River, Montreal, PQ, Canada) were euthanized at $\mathrm{d} 21$ of gestation or were allowed to deliver and the offspring were killed at 2-d intervals between pnd 2 and 22. Pregnant and suckling rats were allowed free access to food and water and were maintained on a 12-h light/dark cycle. All procedures were performed with the approval of the Animal Care Committee of the University of Western Ontario in accordance with the guidelines of the Canadian Council for Animal Care. Rat fetuses and rats up to pnd 6 were euthanized by decapitation. Pregnant mothers and older postnatal-aged animals were killed by $\mathrm{CO}_{2}$ asphyxiation. After death, the pancreas was immediately homogenized in 4 $\mathrm{M}$ guanidine as previously described (20) for RNA isolation, or
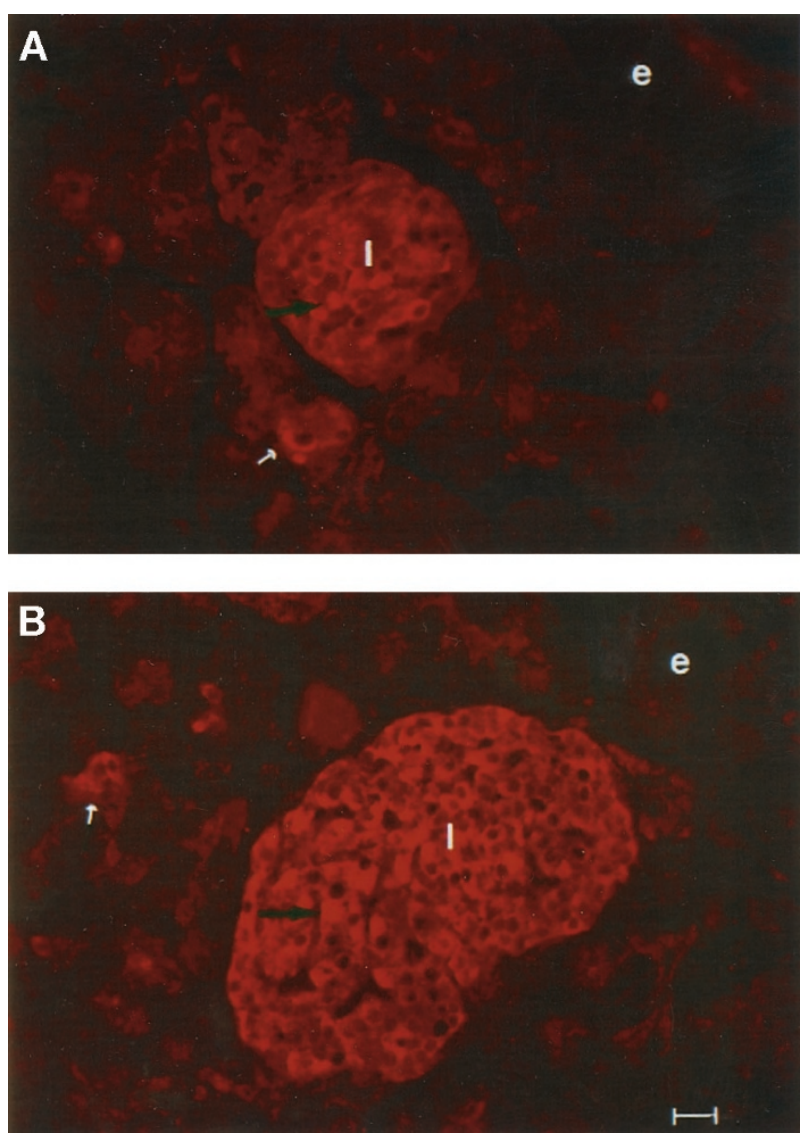

Figure 3. Immunofluorescent localization of $P d x-1$ in pancreas from rats at pnd $4(A)$ and pnd $14(B)$. $i$, islet; $e$, exocrine tissue. Arrows indicates immunofluorescence in the core of the islet containing the $\beta$ cells and in ductal epithelial cells. Magnification bar $=10 \mu \mathrm{m}$. fixed for histology in ice-cold 4\% (wt/vol) paraformaldehyde buffered with $70 \mathrm{mM}$ phosphate buffer $(\mathrm{pH}$ 7.4) containing $0.2 \%(\mathrm{vol} / \mathrm{vol})$ glutaraldehyde for $16 \mathrm{~h}$ at $4{ }^{\circ} \mathrm{C}$, followed by four washes at $4^{\circ} \mathrm{C}$ in PBS over a 48 -h period. Fixed tissues were dehydrated in $70 \%$ (vol/vol) ethanol and embedded in paraffin.

Immunohistochemistry. Histologic sections of pancreas (5 $\mu \mathrm{m})$ were cut and mounted in Superfrost-plus slides (Fisher Scientific, Toronto, ON, Canada). Immunohistochemistry was performed to localize FGF-1, $-2,-4,-6$, or -7 , insulin or glucagon, PCNA, the endothelial cell marker CD31, and the transcription factor Pdx-1 within the pancreas by a modified avidin-biotin peroxidase method (21). Sections were deparaffinized in xylene, rehydrated in descending ethanol series $(100 \%, 90 \%$, and $70 \% \mathrm{vol} / \mathrm{vol})$, and washed in PBS before incubation in $1 \%$ (vol/ $/ \mathrm{vol}$ ) hydrogen peroxide to block endogenous peroxidase activity, followed by a 15 -min incubation in $5 \%(\mathrm{wt} / \mathrm{vol}) \mathrm{BSA}$ in PBS to reduce nonspecific binding. Slides were incubated for either $24 \mathrm{~h}$ or $48 \mathrm{~h}$ at $4^{\circ} \mathrm{C}$ in a humidified chamber with primary antibodies diluted in $0.01 \mathrm{M}$ PBS $(\mathrm{pH}$ $7.5)$ containing $2 \%(\mathrm{wt} / \mathrm{vol}) \mathrm{BSA}$ and $0.01 \%(\mathrm{wt} / \mathrm{vol})$ sodium azide $(100 \mu \mathrm{L} /$ slide). The antisera used were rabbit anti-bovine FGF-1 (1:100) (R\&D Systems, Minneapolis, MN, U.S.A.), rabbit anti-FGF-2 (Ab 773) raised against the 1-24 synthetic fragment of bovine FGF-2 (kindly provided by Dr. Andrew Baird, Ciblex Corporation, San Diego, CA, U.S.A.) (1:500), goat anti-human FGF-4 (1:1000) (R\&D), goat anti-human FGF-6 (1:1000) (R\&D), mouse anti-human FGF-7 (4 $\mu \mathrm{g} / \mathrm{mL})$ (R\&D), guinea pig anti-insulin antibody (1:250) or rabbit anti-porcine glucagon (1:200) (both provided by Dr. T.J. MacDonald, University of Western Ontario, London, ON, Canada), mouse anti-PCNA (1:750) (Sigma Chemical Co., St. Louis, MO, U.S.A.), mouse anti-human cytokeratin 20 (1:50) (Dako Corporation, Santa Barbara, CA, U.S.A.), rabbit anti-human $\alpha$ amylase (1:2000) (Sigma Chemical Co.), or anti-CD31 (1:30) (Dako). All subsequent incubations were performed at room temperature. For the visualization of cytokeratin, tissues were first incubated with Bacto-Trypsin $(0.015 \% \mathrm{wt} / \mathrm{vol}$ in Trizma buffer, pH7.6) (Difco Laboratories, Detroit, MI, U.S.A.) for 45 $\min$ at $37^{\circ} \mathrm{C}$. Biotinylated anti-rabbit IgG $(1: 30)$ (Sigma Chemical Co.), anti-guinea pig $\operatorname{IgG}(1: 500)$, anti-mouse $\operatorname{IgG}(1: 30)$, or anti-goat IgG (1:100) (Vector Laboratories, Burlingame, CA, U.S.A.) were diluted in the same buffer and incubated at room temperature for $2 \mathrm{~h}$. Slides were then washed in PBS and incubated with avidin and biotinylated horseradish peroxidase for $1.5 \mathrm{~h}$. After washing with PBS, peptide immunoreactivity was visualized using the Sigmafast diaminobenzidine (DAB) tablet set (Sigma Chemical Co.). Tissues were counterstained with Carazzi's hematoxylin, dehydrated in ascending ethanol series, cleared with xylene, and mounted under glass coverslips with Eukit (Ruth Wagener Ent., Newmarket, ON, Canada).

To establish the specificity of the antibodies, those against FGF were preabsorbed overnight at $4^{\circ} \mathrm{C}$ with excess homologous ligand $(2 \mu \mathrm{M})(\mathrm{R} \& \mathrm{D})$ before they were applied to the sections. Cross-reactivity of each antisera with other FGF species was negligible according to the suppliers. In all cases staining was abolished. Further controls included substitution of the primary antibody with nonimmune serum or omission of the secondary antisera. 

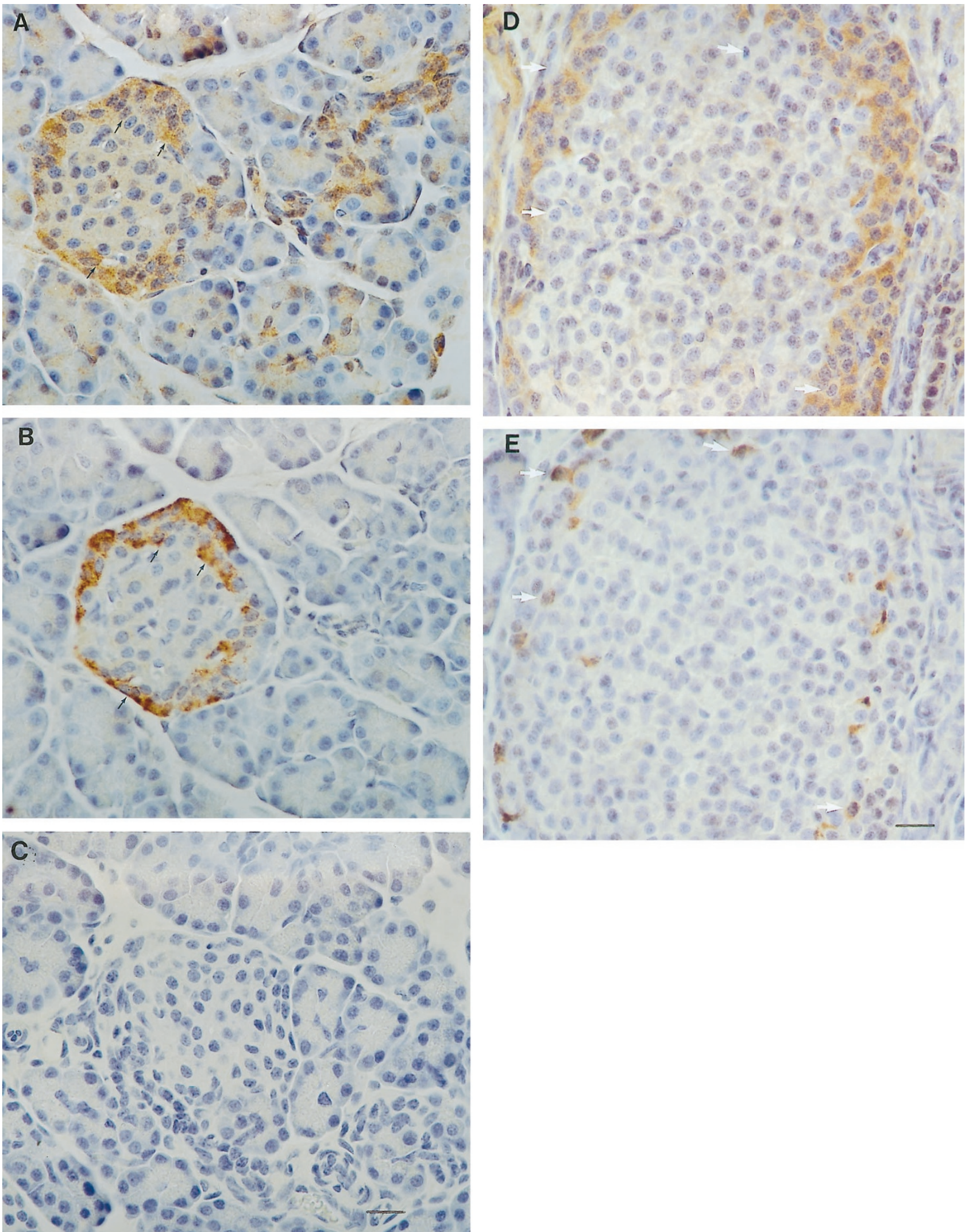

Figure 4. Immunohistochemical localization of FGF-1 $(A)$ and glucagon $(B)$, or FGF-1 $(D)$ and somatostatin $(E)$, in sections from the same islet within rat pancreas at pnd 14. Arrows show the cellular distribution of staining for FGF-1 to glucagon-containing $\alpha$ cells and its absence from somatostatin-containing $\delta$ cells. Panel $C$ is a negative control to show the specificity of the FGF-1 antiserum after preabsorbtion with homologous antigen. Magnification bar $=10 \mu \mathrm{m}$. 

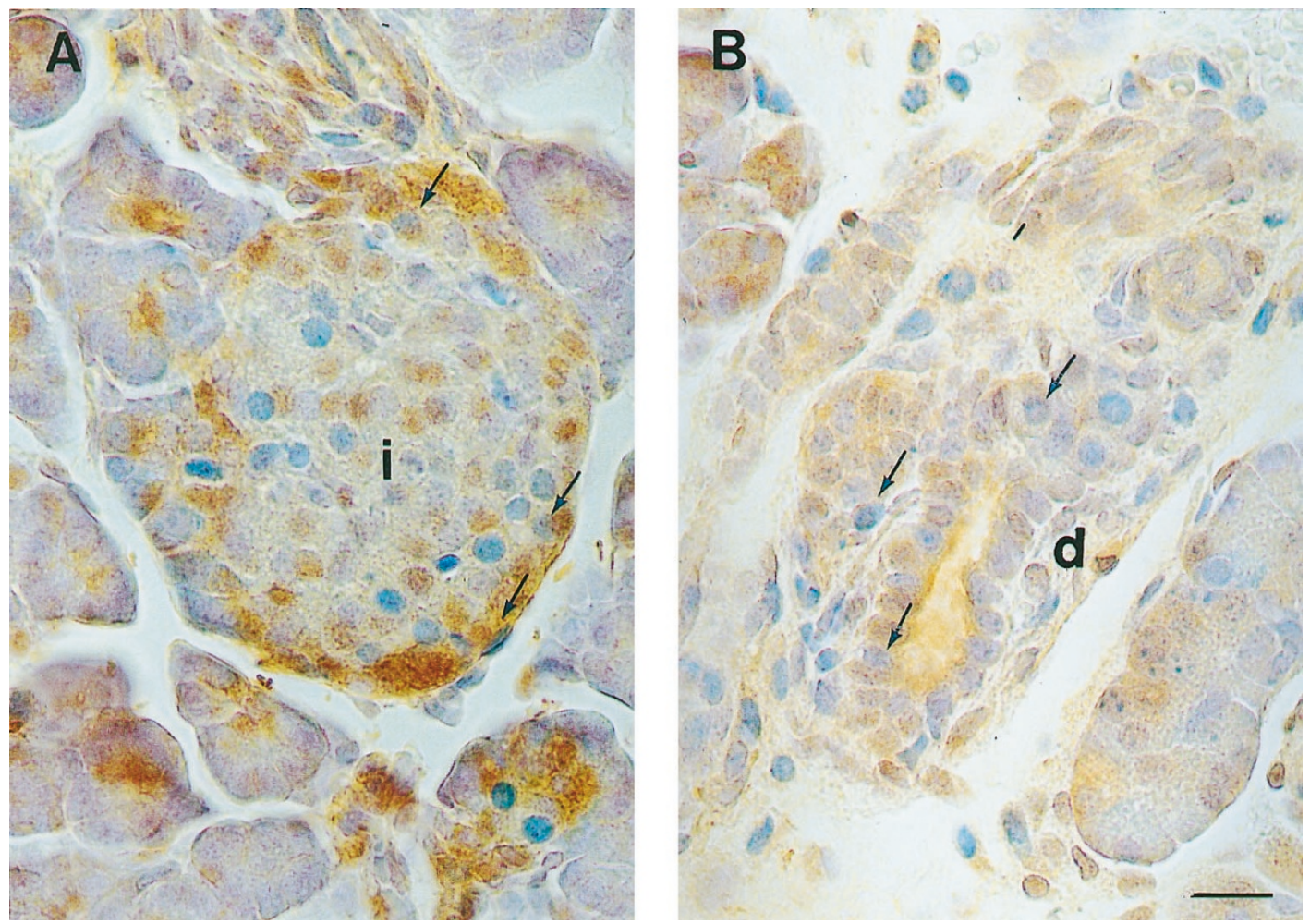

Figure 5. Dual-staining immunohistochemical localization of PCNA (blue) and FGF-1 (brown) within an islet $(A)$, and a pancreatic duct (B) in rat pancreas at pnd 12. $i$, islets; $d$, ductal tissue. Arrows indicate dual immunoreactivity associated with either islet or ductal cells. Magnification bar $=10 \mu \mathrm{m}$.

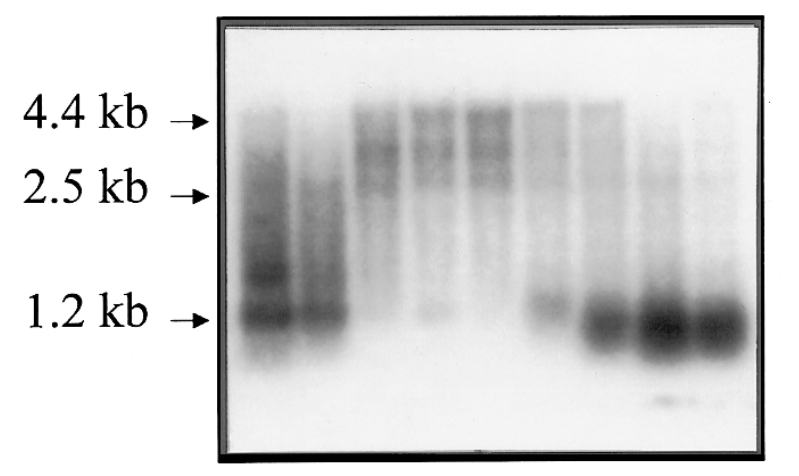

$18 \mathrm{~S}$

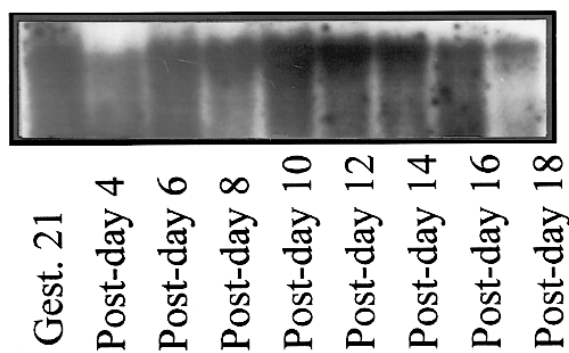

Figure 6. Northern blot hybridization of mRNA for FGF-1 within total RNA extracted from whole rat pancreata for animals of $21 \mathrm{~d}$ gestation to pnd 18 . Three major mRNA transcripts were seen for FGF-1 (4.4, 2.5, and $1.2 \mathrm{~kb})$. The same filter was rehybridized with a cDNA for $18 \mathrm{~S}$ rRNA to demonstrate the efficiency of loading and equivalency of transfer of total RNA. Transcript sizes are shown at left.

Dual staining for FGF-1, -2, or -7 and PCNA was performed by first using the FGF antibody as described above using DAB as a chromogen. Before counterstaining, the sections were further subjected to immunohistochemistry for PCNA using alkaline phosphatase (blue) as a chromogen. Alkaline phospha- tase substrate kit III was obtained from Vector Laboratories. Anti-mouse alkaline phosphatase conjugate (Sigma Chemical Co.) was applied to each section for $1.5 \mathrm{~h}$ at room temperature, and the sections washed and alkaline phosphatase substrate applied for $20 \mathrm{~min}$. Sections were further washed and counterstained with Mayer's haemalum and mounted with Aquamount (Polysciences, Warmington, PA, U.S.A.).

Immunofluorescent microscopy was used to visualize the distribution of the transcription factor, $P d x-1$, in sections of pancreas. The primary antiserum used (1:2500 dilution) was kindly provided by Dr. Christopher Wright (Vanderbilt University, Nashville, TN, U.S.A.). A secondary antibody of donkey anti-rabbit $\operatorname{IgG}$ was conjugated to $\mathrm{CY} 3$ red fluorochrome (1:1000, ML Grade, Jackson ImmunoResearch Labs, Inc., West Grove, PA, U.S.A.).

In situ hybridization. A 486 bp antisense cDNA and a 461 bp sense strand cDNA encoding human FGF-2 in pBluescript SK + (Stratagene, San Diego, CA, U.S.A.) were kindly provided by Dr. Andrew Baird (Ciblex Corporation, San Diego, CA, U.S.A.). The restriction enzymes (GIBCO-BRL, Burlington, ON, Canada) and RNA polymerases (Promega, Madison, WI, U.S.A.) used to linearize the plasmid containing these cDNAs and to generate ${ }^{35} \mathrm{~S}$-radiolabeled riboprobes were, for the antisense hFGF-2, SAL1/T7, and the sense hFGF-2 EcoRI/ T7. Thio $\left[{ }^{35} \mathrm{~S}\right]$ UTP $(400 \mathrm{Ci} / \mathrm{mM})$ was obtained from ICN (Irvine, CA, U.S.A.). Radiolabeled antisense and sense cDNA probes for hFGF-2 were transcribed using a Riboprobe GEMINI II core system (Promega) and $\left[{ }^{35} \mathrm{~S}\right]$ UTP was incorporated with a T7 RNA polymerase as described previously (20). Fixed tissues were dewaxed and permeabilized with $0.2 \%$ (vol/vol) 

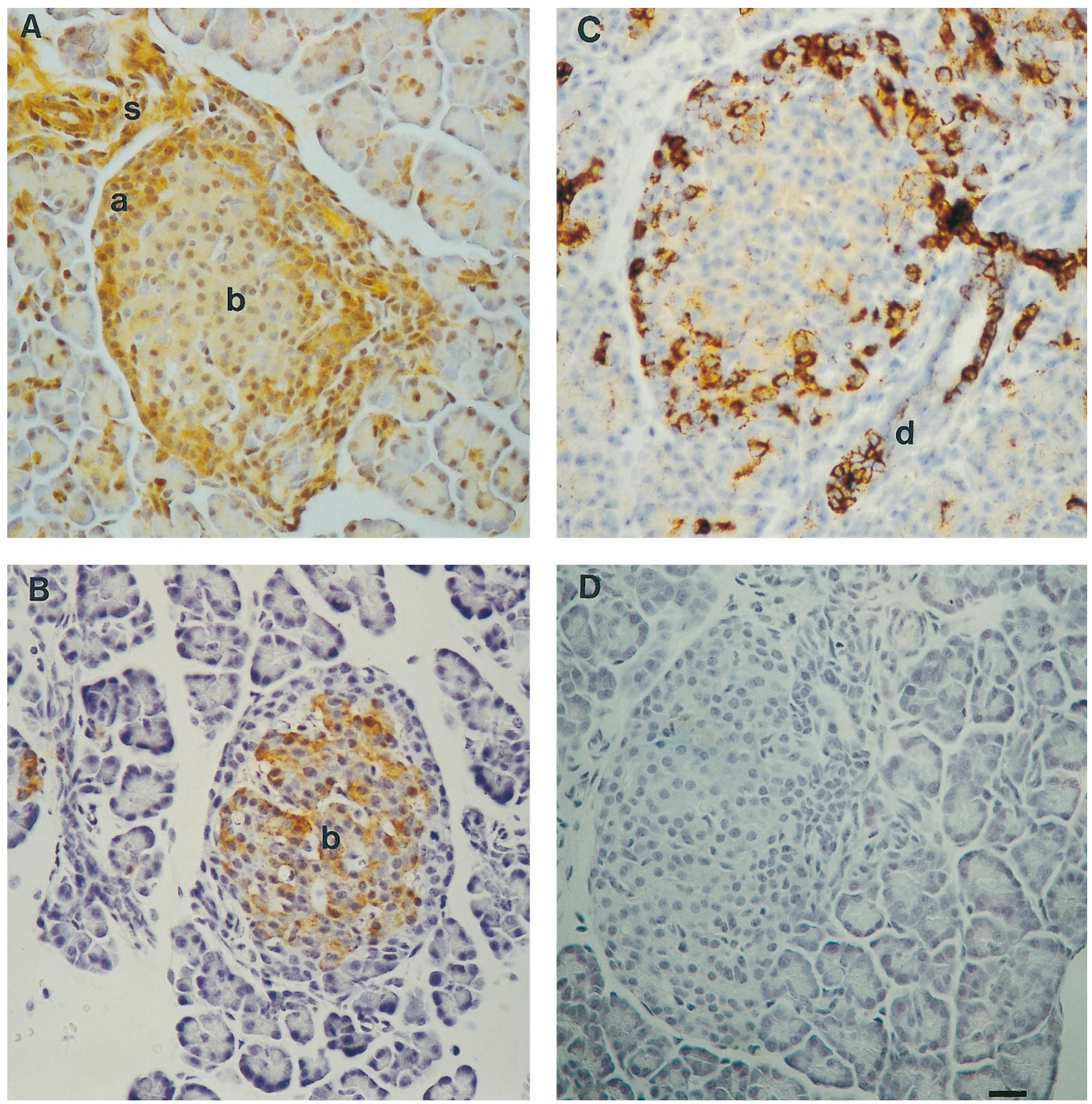

Figure 7. Immunohistochemical localization of FGF-2 $(A)$, insulin $(B)$, and cytokeratin $(C)$ in an islet from a rat pancreas at pnd 14 . Panel $D$ is a negative control to show the specificity of the FGF-1 antiserum after preabsorbtion with homologous antigen. Staining is shown over $\alpha$ and $\beta$ cells of the islets ( $a$ and $b$ ), ductal tissue $(d)$, or stroma $(s)$. Magnification bar $=10 \mu \mathrm{m}$.

Triton X-100 and in situ hybridization performed following the protocol that has been described in detail by us (22).

Northern blot analysis. RNA was extracted from the pancreata using the thiocyanate guanidinium cesium chloride method immediately after killing the animals as previously described (20). The integrity and relative amounts of RNA from each tissue were assessed by size separation by $1 \%$ agarose gel electrophoresis and RNA visualized with ethidium bromide. Tissues in which ribosomal RNA showed degrada- tion were discarded. A hFGF-2 cDNA was obtained from Dr. A. Baird and cDNA encoding fragments of rFGF-1 and rFGF-7 were generated from total newborn rat pancreatic RNA using reverse transcriptase PCR (RT-PCR) as described (23) using the ACCESS RT-PCR kit (Promega). The products obtained from primers for rFGF-1 and rFGF-7 $(24,25)$ were 400 bp and $570 \mathrm{bp}$, respectively, and were inserted in a PGEM-T vector (Promega) and grown in competent bacteria, to obtain largescale DNA. The restriction enzymes used to digest the inserts 

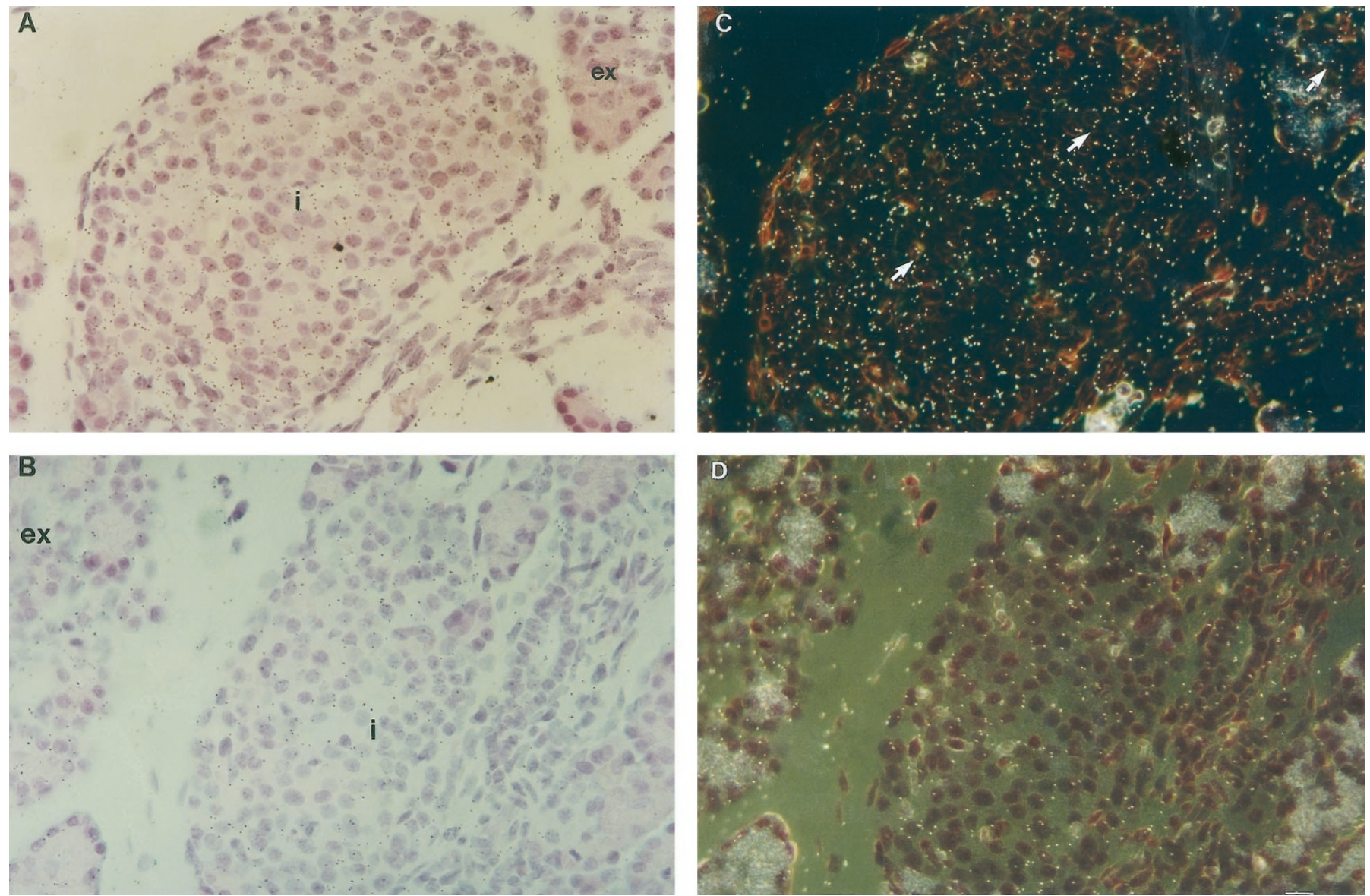

Figure 8. Light field $(A$ and $B)$ and dark field $(C$ and $D)$ microscopy to visualize mRNA signal encoding FGF-2 by in situ hybridization in tissue sections of rat pancreas from 6-d-old animals. Panels $A$ and $C$ show hybridization with an antisense cRNA probe. FGF-2 mRNA is abundant (arrows) within the islets ( $i$ ) and in some acinar cells $(e x)$. Panels $B$ and $D$ show a control hybridization with a sense strand cRNA. Magnification bar $=10 \mu \mathrm{m}$.

were SstI and Sst2 (GIBCO-BRL). An 18 S ribosomal RNA cDNA was kindly provided by Dr. D. Denhardt (Rutgers University, Piscataway, NJ, U.S.A.). This was used to determine equality of RNA loading and transfer.

Northern blot hybridization was performed as previously described by us for FGF-2 (22) using $20 \mu \mathrm{g}$ total RNA per lane on $1 \%$ agarose, $2.2 \mathrm{M}$ formaldehyde gels. The RNA was blotted by capillary transfer onto Zeta-probe (Bio-Rad, Hercules, CA, U.S.A.) membranes and hybridization performed with $\mathrm{hFGF}-2, \mathrm{rFGF} 1, \mathrm{rFGF}-7$, or $18 \mathrm{~S}$ RNA cDNA radiolabeled with $\left[{ }^{32} \mathrm{P}\right] \mathrm{dCTP}$ to a specific activity of $10^{9} \mathrm{dpm} / \mu \mathrm{g}$ DNA. Hybridizations were carried out at $42^{\circ} \mathrm{C}$ overnight with $2 \times 10^{6} \mathrm{cpm} / \mathrm{mL}$ labeled cDNA probes. Between hybridizations with different cDNA probes, membranes were washed with $0.01 \times$ standard saline citrate and $0.5(\mathrm{wt} / \mathrm{vol}) \mathrm{SDS}$ at $80^{\circ} \mathrm{C}$ two to three times for $15 \mathrm{~min}$ to remove previous radiolabeled cDNA.

Islet isolation and culture. The isolation technique for the production of $\beta$-cell-rich islets used collagenase digestion and was modified from that of Hellerstrom et al. (26). It has been described in detail by us previously (27). By the beginning of the experimental incubations, islets consisted of more than $90 \% \beta$ cells when assessed by immunohistochemistry for insulin. Pregnant rats were euthanized and the fetuses were removed and euthanized by decapitation. The average number of fetuses per mother was 12 , and $40-50$ fetal pancreata were obtained in each experimental group from three to four mothers. After digestion, dispersed tissue was distributed in $1 \mathrm{~mL}$ volumes into tissue culture petri dishes $(100 \mathrm{~mm}$; A/S NUNC, Toronto, ON, Canada) containing $14 \mathrm{~mL}$ tissue culture medium (RPMI 1640, pH 7.4, containing $11.1 \mathrm{mM}$ glucose and $25 \mathrm{mM}$ $N$-2-hydroxyethylpiperazine- $N^{\prime}$-2-ethanesulfonic acid [HEPES; GIBCO], supplemented with antibiotics $[100 \mathrm{U} / \mathrm{mL}$ penicillin and $0.1 \mathrm{mg} / \mathrm{mL}$ streptomycin], Fungizone $[0.25 \mu \mathrm{g} /$ $\mathrm{mL}]$, and $10 \%$ [vol/vol] heat-inactivated, virus- and mycoplasma-free fetal bovine serum [GIBCO]). The culture plates were incubated for $8 \mathrm{~d}$ at $37^{\circ} \mathrm{C}$ in a humidified atmosphere of $5 \%$ $\mathrm{CO}_{2}$ in air and the medium changed daily. Islets were harvested and transferred to nontissue culture grade petri dishes (100 mm; Falcon, Lincoln Park, NJ, U.S.A.) that did not permit cell attachment, containing the same tissue culture medium, until the experimental or treatment period. A typical yield of islets for 40-50 pancreata was approximately $1500-2000$.

At the beginning of the treatment period, the islets were distributed in equal batches (100-200 islets per plate) onto nontissue culture grade petri dishes $(50 \mathrm{~mm}$, Falcon) containing $1 \mathrm{~mL}$ tissue culture medium. Culture medium consisted of glucose-free Dulbecco's modified Eagle's medium (DMEM; Imperial Laboratories, Andover, Hants, U.K.) pH 7.4, containing antibiotics and Fungizone (as above), supplemented with 2 


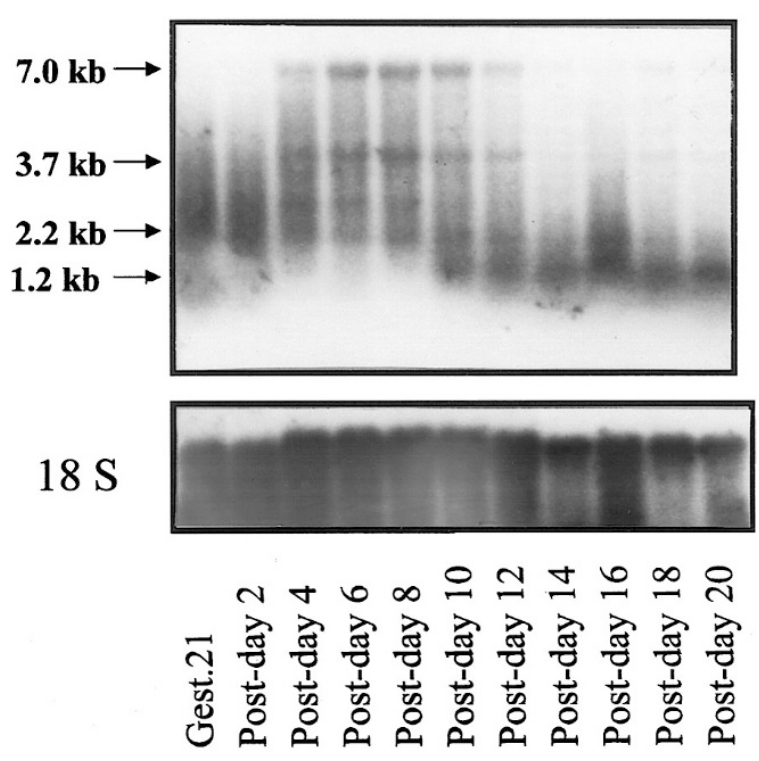

Figure 9. Northern blot hybridization of mRNA for FGF-2 within total RNA extracted from whole rat pancreata for animals of $21 \mathrm{~d}$ gestation to pnd 20 . Three major mRNA transcripts were seen for FGF-2 (7, 3.7, and $1.2 \mathrm{~kb})$. The same filter was rehybridized with a cDNA for $18 \mathrm{~S}$ rRNA to demonstrate the efficiency of loading and equivalency of transfer of total RNA. Transcript sizes are shown at left.

$\mathrm{mM}$ glutamine (GIBCO), $2 \mathrm{mg} / \mathrm{mL}$ BSA, and $8.7 \mathrm{mM}$ glucose. Medium was further supplemented with recombinant human FGF-1, -2, or -7 (0.1-16 nM) (R\&D), or IGF-II (0.1-16 nM) (Bachem Inc., Torrance, CA, U.S.A.). The islets were maintained in culture for a further $48 \mathrm{~h}$. For the final $24 \mathrm{~h}$ of the treatment period, the culture medium was supplemented with 1 $\mu \mathrm{Ci}\left[\right.$ methyl- $\left.{ }^{3} \mathrm{H}\right]$ thymidine $/ \mathrm{mL}(20 \mathrm{Ci} / \mathrm{mmol} ; \mathrm{ICN})$. At the end of the treatment period islets were washed in PBS and processed for liquid scintillation counting.

After culture, the islets were washed in $500 \mu \mathrm{L}$ PBS and disrupted ultrasonically in microcentrifuge tubes containing $250 \mu \mathrm{L}$ distilled water. Two $50 \mu \mathrm{L}$ aliquots of homogenate were removed and the DNA was precipitated in $500 \mu \mathrm{L}$ ice-cold 5\% trichloroacetic acid. The precipitates were collected by filtration through a glass fiber disc $(2.5 \mathrm{~cm}$; Whatman GF/A, Whatman International Ltd., Maidstone, Kent, U.K.). Any remaining free isotope was removed by washing with distilled water. The radioactivity on the filters was determined by liquid scintillation counting and the incorporation of $\left[{ }^{3} \mathrm{H}\right]$ thymidine expressed as $\mathrm{dpm} / \mu \mathrm{g}$ DNA. Islet DNA was measured by fluorometry using Hoechst fluorochrome 33258 (Aldrich Chemical Co., Milwaukee, WI, U.S.A.) as described previously (27).

Image analysis and statistics. Morphometric analysis was performed using a Zeiss transmitted light microscope at a magnification of $\times 250$ or $\times 400$. Analyses were performed with Northern Eclipse version 2.0 morphometric analysis software (Empix Imaging Co., Mississauga, ON, Canada). The percentage of islet cells immunopositive for FGF, insulin, glucagon, or PCNA was calculated at each age from up to five sections of each pancreas representing predominantly the head regions. Sections chosen contained at least five islets, and pancreata from up to five animals were examined for each age. Individual cell area and total areas of immunoreactive cells within islets were circled for image analysis and selected by gray-level threshold. Differences between mean values for variables within individual experiments were compared statistically by two-way ANOVA, followed by a Scheffé test. Ex-
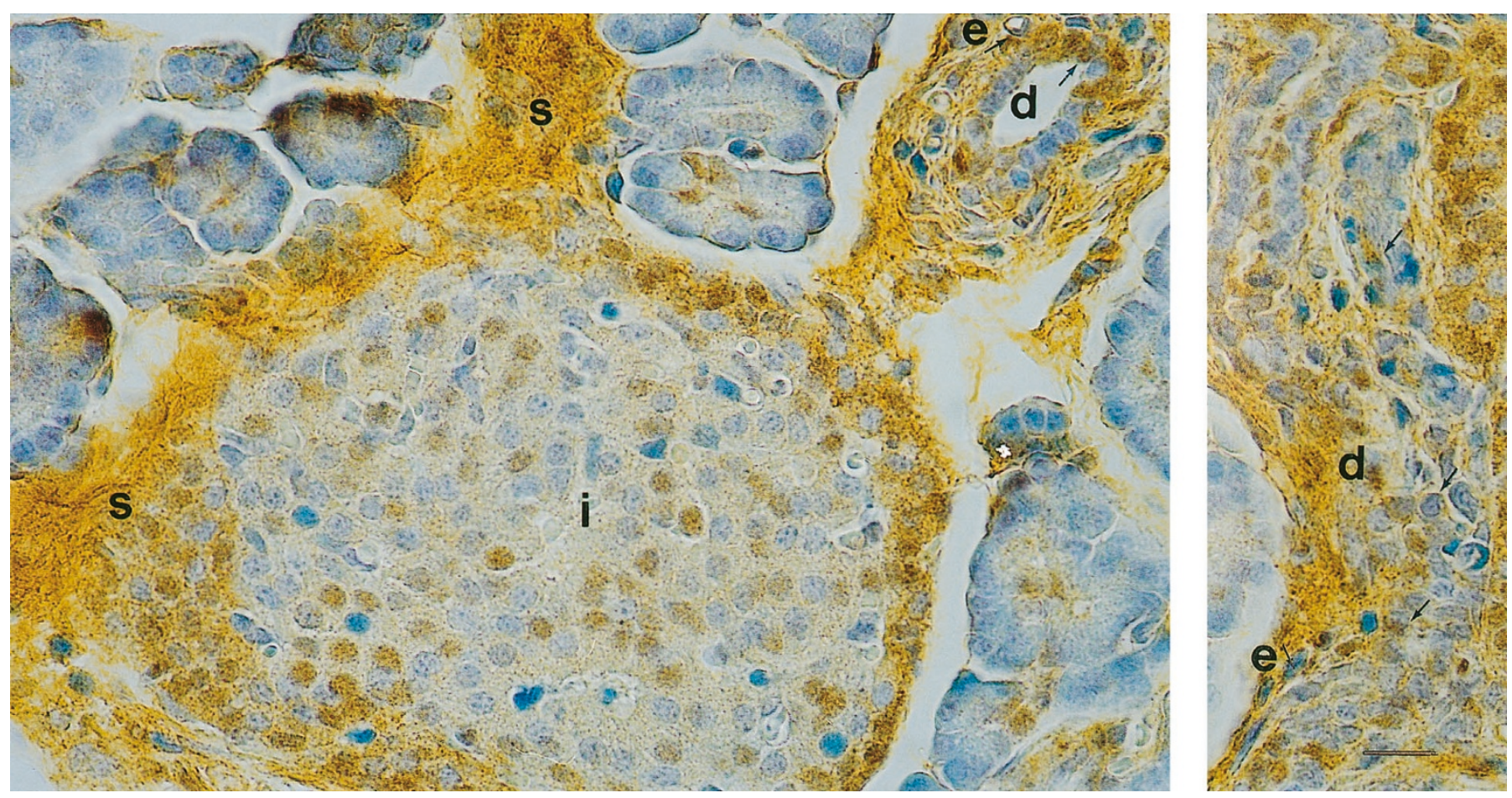

Figure 10. Dual-staining immunohistochemical localization of PCNA (blue) and FGF-2 (brown) within an islet $(i)$, stroma and matrix $(s)$, pancreatic ducts $(d)$, and vascular endothelium $(e)$ in rat pancreas at pnd 12. Arrows indicate dual immunoreactivity associated with either islet or ductal cells. Magnification bar $=$ $10 \mu \mathrm{m}$. 

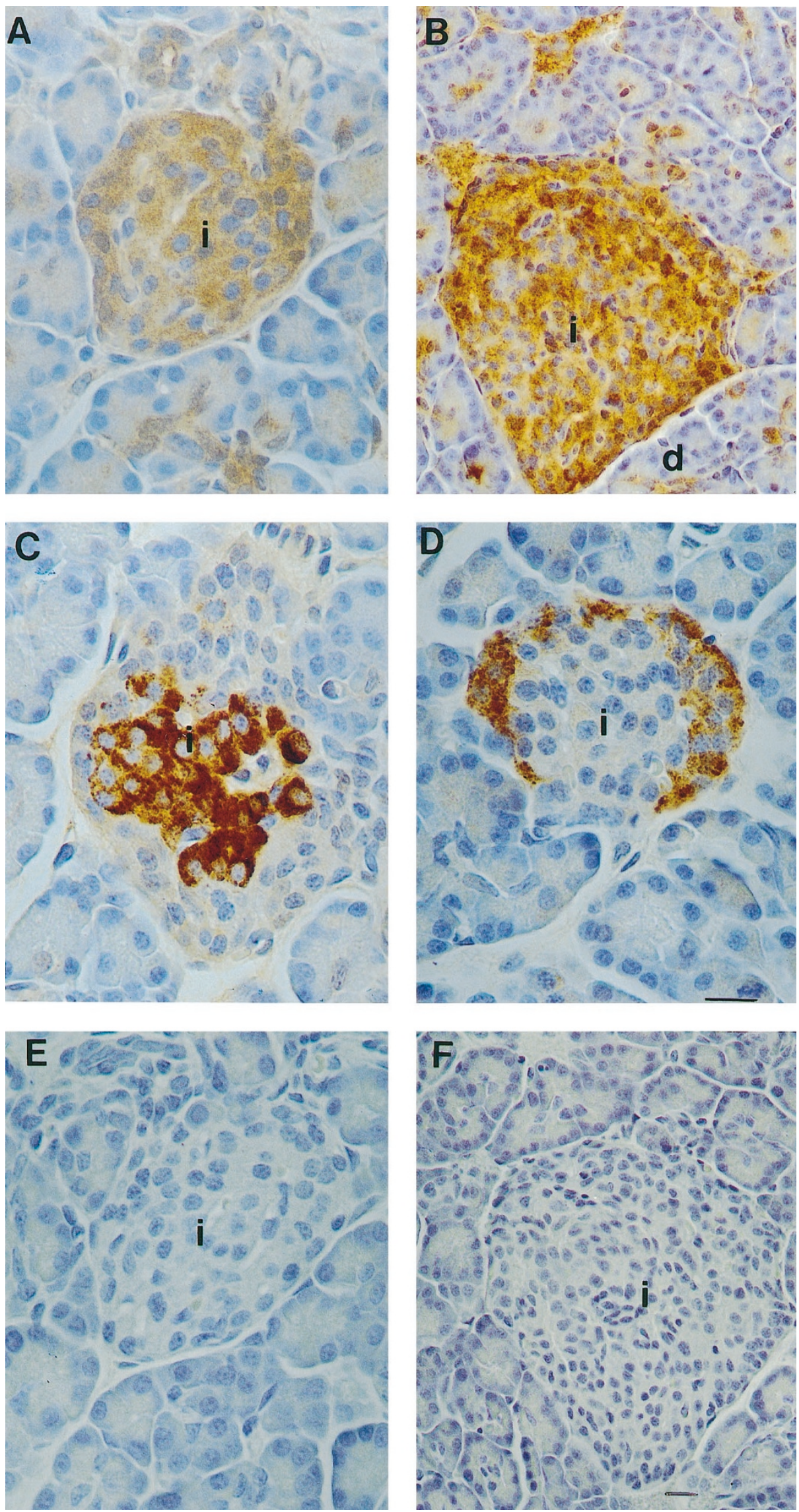

Figure 11. Immunohistochemical localization of FGF-4 $(A)$ and FGF-6 $(B)$, insulin $(C)$, and glucagon $(D)$ in rat pancreas at pnd 12-14. Arrows show the cellular distribution of staining to islet cells $(i)$ and ductal tissue $(d)$. Panels $E$ and $F$ show negative controls where the primary antisera for FGF-4 and -6, respectively, were preabsorbed with homologous antigen. Magnification bar $=10 \mu \mathrm{m}$ in $A, C, D$, and $E$ and $15 \mu \mathrm{m}$ in $B$ and $F$. 

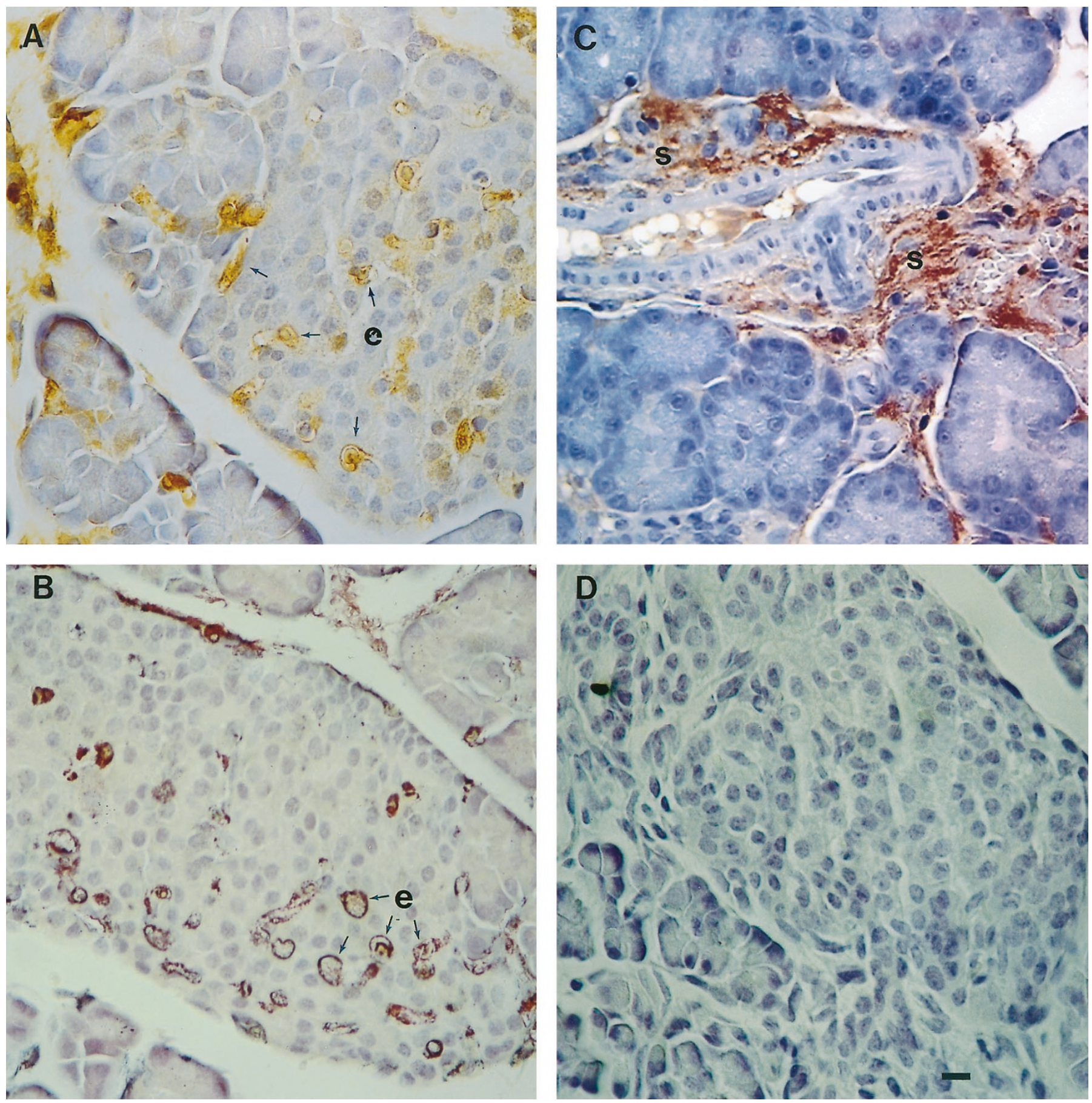

Figure 12. Immunohistochemical localization of FGF-7 $(A$ and $C)$, and $\operatorname{CD} 31(B)$ in rat pancreas at pnd 14. Arrows show the cellular distribution of staining to endothelial cells $(e)$ or stroma $(s)$. Panel $D$ is a negative control to show the specificity of the FGF-7 antiserum after preabsorbtion with homologous antigen. Magnification bar $=10 \mu \mathrm{m}$.

periments on islet DNA synthesis were repeated three times using islets from separate pools of animals.

\section{RESULTS}

Cell replication. Identification of the islet $\alpha$ - and $\beta$-cell populations, and of the ductal epithelial and exocrine tissue compartments, was achieved by immunohistochemistry for glucagon, insulin, cytokeratin, and amylase, respectively (Fig. 1). The ductal epithelial cell marker used, cytokeratin 20, was also present in cells in the outer parts of the islets of Langerhans. Immunohistochemistry for PCNA was used to determine whether the relative incidence of cell replication within and between tissue compartments altered substantially between birth and weaning. Only 3 to $4 \%$ of islet cells were undergoing cell replication in late fetal life, and this did not significantly alter at ages up to pnd 21 (Table 1 and Fig. 2). The percentage of ductal epithelial cells, from which new endocrine cells derive, which stained for PCNA was significantly greater at $d$ 10-14 than in late fetal life (Fig. $2 B$ and $C$, and Table 1), and 
abundant cell replication was seen within the exocrine compartment at this time compared with earlier or later ages. Immunofluorescent signal for the transcription factor $P d x-1$, which is involved both in $\beta$-cell ontogeny and subsequent insulin gene expression, was present throughout the central core of islet $\beta$ cells at all ages with equal intensity (Fig. 3). $P d x$-1 was also present within focal groups of ductal epithelial cells, particularly between d 10 and 14, which presumably represented sites of endocrine cell neogenesis.

$\boldsymbol{F G F - 1 . ~ F G F - 1 ~ w a s ~ m a i n l y ~ p r e s e n t ~ i n ~ e n d o c r i n e ~ c e l l s ~ a r o u n d ~}$ the edges of the islets (Fig. 4A). These were identified as $\alpha$ cells from the presence of glucagon within sections from the same islets (Fig. 4B), whereas many of the somatostatincontaining $\delta$ cells did not contain immunoreactive FGF- 1 when assessed in consecutive sections (Fig. $4 D$ and $E$ ). When tissues were incubated with antiserum preabsorbed with excess FGF-1 peptide, the staining was completely abolished, confirming the specificity of the antibody (Fig. 4C). FGF-1 was seen within fetal islets, but only $7 \%$ of islet cells were immunopositive. This increased with age to $26 \%$ of cells by pnd 22 (Table 1 ). Because the percentage contribution of $\alpha$ cells to islets remained almost constant at approximately $15 \%$ throughout this period (Table 1), only about half of the $\alpha$ cells contain detectable FGF-1 at birth. Dual-label immunohistochemistry for FGF-1 and PCNA showed that many of the islet cells undergoing DNA synthesis in the outer region of the islets also contained FGF-1 (Fig. 5A). FGF-1 immunoreactivity was also present in ductal epithelium, whereas weak staining was seen in acinar cells. In ductal epithelium, the percentage of immunopositive cells increased to a maximum of $71 \%$ at $d 14$, and declined to $33 \%$ by d 22 (Table 1 ). This paralleled changes in cell replication determined by PCNA staining, and dual-label immunohistochemistry showed a colocalization in many cells (Fig. 5B). To determine whether the changes in peptide distribution reflected changes in total pancreatic mRNA abundance for FGF-1, Northern blot hybridization was performed. Three mRNA transcripts of $4.4 \mathrm{~kb}, 2.5 \mathrm{~kb}$, and $1.2 \mathrm{~kb}$ were detected (Fig. 6). FGF-1 mRNA was expressed at all ages in the pancreas, but the dominant transcript size changed with age, the $1.2 \mathrm{~kb}$ transcript being most abundant up to $\mathrm{d} 4$ and after $\mathrm{d}$ 10 , whereas the larger, more abundant transcripts were preferentially expressed between d 6 and 10 .

$\boldsymbol{F G} \boldsymbol{F}$-2. Similar analyses were performed for FGF-2. FGF-2 immunoreactivity was localized in both exocrine and endocrine cells, in small ducts adjacent to the islets, in the vascular endothelium of capillaries, and throughout the stromal cells and associated extracellular matrix (Fig. 7A), as determined by staining of sections from the same islets with antisera against insulin and cytokeratin (Fig. $7 B$ and $C$ ). Preabsorbtion of FGF-2 antibody with excess ligand completely abolished the staining (Fig. 7D). Within the islets, FGF-2 staining was widespread, but was more intense within the outer $\alpha$ cell population (Fig. 7A). Nuclear staining for FGF-2 was often seen in acinar cells and islet cells. The percentage area of islets containing FGF-2 was only $14 \%$ in late fetal life, but increased to $29 \%$ by pnd 10 and did not significantly change until weaning (Table 1). The distribution of FGF-2 mRNA was examined by in situ hybridization to determine whether the distribution of peptide reflected changes in gene transcription within the same cell populations. In late fetal life there was little detectable signal. However, by d 6 FGF-2 mRNA was abundant throughout islet cells and in ductal epithelium, and was also present, but less abundant, in acinar tissue (Fig. 8). Hybridization was specific because very low signal was visualized when using the sense strand cRNA. When analyzed by Northern blot, mRNA for FGF-2 was seen at all ages within pancreas but was most abundant between $\mathrm{d} 6$ and 12, although the dominant mRNA transcript sizes varied with age (Fig. 9). In early postnatal life and after d 12 a transcript of $2.2 \mathrm{~kb}$ predominated, but between $\mathrm{d} 6$ and 12 the major transcripts were $7 \mathrm{~kb}$ and $3.7 \mathrm{~kb}$. Changes in the abundance of FGF-2 mRNA or the extent of peptide immunoreactivity in islets showed no relationship to PCNA labeling in islet cells, and little colocalization of PCNA and FGF-2 was seen (Fig. 10), suggesting that FGF-2 may not function primarily as an autocrine mitogen for islet endocrine cells. In contrast, in the ductal epithelial cells colocalization of FGF-2 and PCNA was more frequently seen (Fig. 10B).

$\boldsymbol{F G F - 4 , ~ - 6 , ~ a n d ~ - 7 . ~ I m m u n o r e a c t i v e ~ F G F - 4 ~ a n d ~ F G F - 6 ~ w e r e ~}$ both localized strongly within islets including both the $\alpha$ - and $\beta$-cell-rich regions as determined by staining for insulin or glucagon within the same islets (Fig. $11 A$ to $D$ ). The relative distribution of FGF-4 did not significantly change with age, but FGF-6 gradually increased to over $60 \%$ of islet area on d 14 before declining thereafter (Table 1). FGF-4 immunoreactivity was also strong in vascular endothelium and FGF-6 within ductal epithelium. Both FGF-4 and -6 were located within a discrete subpopulation of acinar cells. In contrast, FGF-7 was largely absent from islet endocrine cells, but was present in intraislet and extraislet endothelial cells that were identified with the endothelial cell marker, CD31 (Fig. $12 A$ and $B$ ). Abundant immunoreactivity for FGF-7 was also located within the stromal mesenchymal tissue surrounding islets, both within cell cytoplasm and associated with extracellular matrix. Staining was particularly intense around pancreatic ducts, but was absent from the ductal epithelial cells (Fig. 12C). FGF-7 immunoreactivity was most apparent in late fetal life and up to pnd 16, but was reduced in intensity at pnd 22. Preabsorbtion of the FGF-7 antiserum with excess ligand abolished staining. Northern blot hybridization was performed to determine whether the changes in peptide distribution reflected changes in total organ mRNA. The highest levels of FGF-7 mRNA present in whole pancreas were found between $\mathrm{d} 4$ and 12 with a single mRNA transcript of $2.4 \mathrm{~kb}$ (Fig. 13).

Mitogenic effects on islets. To determine the likely effects of some of the FGF observed to be present in the developing rat pancreas on islet cell proliferation, isolated islets were prepared from fetal rats on gestational $\mathrm{d} 21$ and maintained in vitro for $8 \mathrm{~d}$ before exposure to exogenous FGF-1, -2, or -7. All three FGF stimulated an increase in $\left[{ }^{3} \mathrm{H}\right]$ thymidine incorporation into islet cell DNA (Fig. 14A). FGF-7 was a more potent mitogen for rat islets with a half-maximal concentration of approximately $0.1 \mathrm{nM}$. FGF- 1 and -2 both had half-maximal responses at approximately $0.5 \mathrm{nM}$, and were maximal at 2 $\mathrm{nM}$. The mitogenic actions of FGF-2 and IGF-II, a known autocrine mitogen for fetal and neonatal rat islets, were addi- 

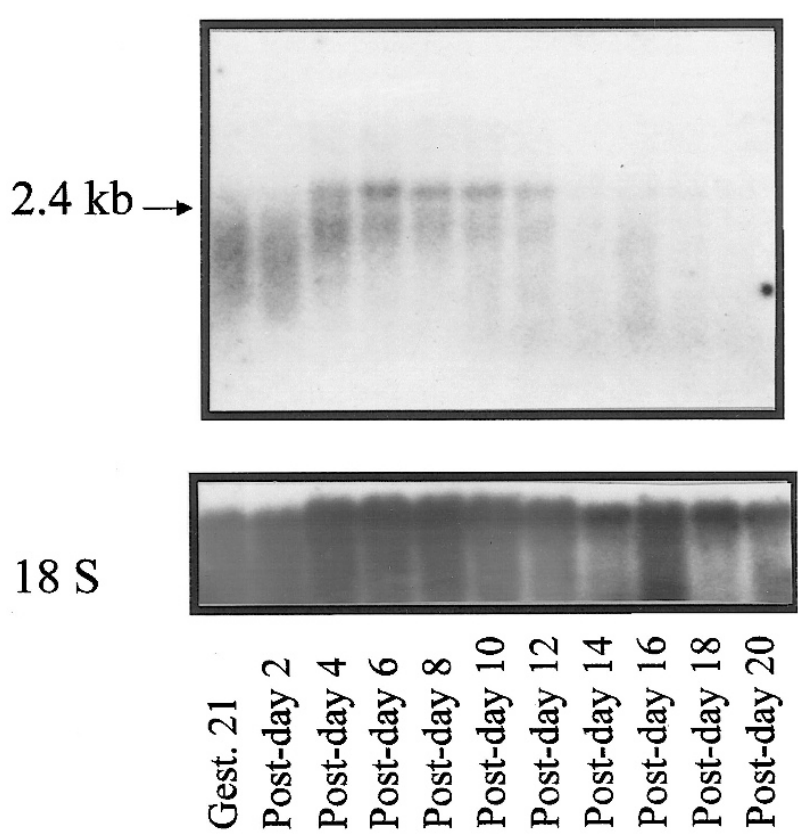

Figure 13. Northern blot hybridization of mRNA for FGF7 within total RNA extracted from whole rat pancreata for animals of $21 \mathrm{~d}$ gestation to pnd 20. A single transcript for FGF-7 (2.4 kb) was seen. Each panel represents a separate Northern blot. The same filter was rehybridized with a cDNA for $18 \mathrm{~S}$ rRNA to demonstrate the efficiency of loading and equivalency of transfer of total RNA. Transcript size is shown at left.

tive, their combined effects being approximately double that of their individual actions for maximally effective concentrations of $8 \mathrm{mM}$ or greater (Fig. 14B).

\section{DISCUSSION}

Late fetal and early postnatal life represents a period of substantial restructuring of the rat endocrine pancreas. We have shown previously that a wave of $\beta$-cell apoptosis occurs $12-14 \mathrm{~d}$ after birth (19). Because total $\beta$-cell mass does not decline appreciably at this time (28), it seems likely that a new $\beta$-cell cohort is formed, either from neogenesis within the pancreatic ductal epithelia, or by replication of the remaining $\beta$ cells within the islets. We found that there was no substantial increase in the replication rate of islet cells between birth and pnd 22, but there was a transient increase in PCNA labeling in ductal epithelial cells, which was maximal on d 14. Both islets and ductal epithelium expressed the transcription factor $P d x-1$, which is involved in the formation of endocrine cell lineages from ductal epithelium, and also controls glucose transporter-2 and insulin gene expression in mature $\beta$ cells (29). FGF-1 and -2 and their receptor, FGFR1, are all detected in normal adult human pancreas, and are highly expressed in advanced pancreatic tumors (30), making members of the FGF family strong candidate trophic factors within the process of developmental islet neogenesis and replication. This study shows that a distinct localization exists for different FGF in the endocrine and epithelial ductal cell populations during rat pancreatic maturation.

Our data are in agreement with the findings of others for the adult rat digestive system where FGF-1 immunoreactivity was localized in the periphery of the islets, mainly within $\alpha$ cells,
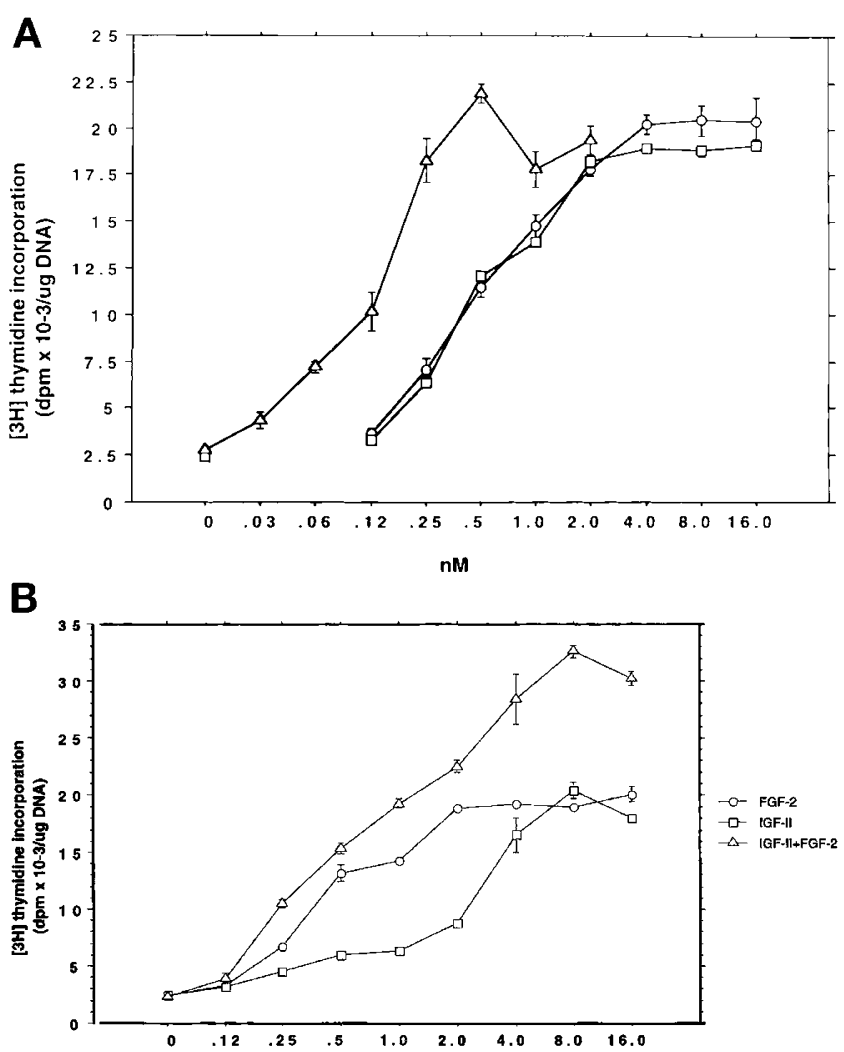

Figure 14. Estimation of DNA synthesis $\left(\mathrm{dpm}\left[{ }^{3} \mathrm{H}\right]\right.$ thymidine $\times 10^{-3} / \mu \mathrm{g}$ DNA) for islets isolated from rats on d 21 gestation and subsequently incubated in vitro for $8 \mathrm{~d}$ before exposure to increasing concentrations of $(A)$ FGF-1 $(\bigcirc)$, FGF-2 $(\square)$, or FGF-7 $(\triangle)$ ); or $(B)$ IGF-II (IGF-II) $(\bigcirc)$, FGF-2 ( $\square$ ), or FGF-2 together with IGF-II at the same molar concentrations $(\triangle)$. Figures represent mean values \pm SEM, $n=4$.

and in the mucosal epithelia from the jejunum to the colon, particularly in the L cells, which express glucagon-like polypeptides (GLP)-1 and -2 (31). Within the islet $\alpha$ cells we found that, whereas many cells undergoing DNA synthesis contained immunoreactive FGF-1, most cells containing FGF-1 did not stain for PCNA, which would argue against a purely mitogenic role for FGF-1. A localization of FGF-1 in both $\alpha$ cells and $\mathrm{L}$ cells suggests a role in the maturation and/or control of release of several products of the proglucagon gene. FGF-2 was more widely distributed within the islets and in situ hybridization showed that mRNA was located in both the $\alpha$ and $\beta$-cell-rich regions. Both exogenous FGF-1 and -2 were mitogenic for isolated rat islets, and the effects of FGF-2 were additive to those of IGF-II, which is an important paracrine mitogen for islet cells (32). However, whereas peptide distribution in islets increased with postnatal age, there was a poor correlation between the presence of FGF-2 immunoreactivity and PCNA labeling within the $\beta$-cell-rich core. This suggests that the role of FGF-2 within the islets may be more related to endocrine function.

We found that both FGF-1 and -2 were also localized in the exocrine pancreas, where they have been shown to control amylase release from pancreatic acini (33). Similarly, both FGF species were also localized to the ductal epithelial cells where colocalization with PCNA was often seen and $P d x-1$ is expressed. This would suggest a possible role in ductal cell 
proliferation or islet cell neogenesis. Exogenous FGF-1 increased the insulin content of fetal rat "islet-like structures" (11), suggesting a potentiation of $\beta$-cell generation. In the present study, the relative number of ductal epithelial cells containing immunoreactive FGF-1, and to a lesser extent FGF-2, was transiently increased between pnd 12 and 14 when the nuclear labeling index with PCNA was also maximal. A functional link between ductal cell replication and FGF expression is also supported by changes in mRNA. Several mRNA encoding FGF-1 or -2 were detected in pancreas between late fetal life and weaning, including $4.4 \mathrm{~kb}$ and $2.5 \mathrm{~kb}$ species for FGF-1, as reported in other developing tissues, and $7 \mathrm{~kb}, 3.7$ $\mathrm{kb}$, and $2.2 \mathrm{~kb}$ species for FGF-2 $(7,34)$. The distribution of transcripts varied with age, with the larger species predominating between pnd 6 and 12 . Both FGF-1 and -2 have multiple molecular size forms from $18 \mathrm{kD}$ to $24 \mathrm{kD}$ encoded from separate mRNA (7). The larger forms have a predominantly nuclear localization associated with cell cycle events and times of rapid cell proliferation (35). The FGF-1 gene also utilizes alternative promoters and splicing to generate a number of mRNA transcripts that vary between tissues and with development (36), which may account for the variation in transcript sizes seen in pancreas with age.

FGF-7 is not obligatory for pancreatic endocrine development because gene inactivation by homologous recombination resulted in viable offspring without any obvious metabolic or growth defects (37). Nevertheless, systemic injection of FGF-7 into adult rats for up to $2 \mathrm{wk}$ caused a rapid increase in DNA synthesis within the ductal epithelium of intercalating, intralobular, and interlobular ducts within $24 \mathrm{~h}$ (38). Pancreatic duct hyperplasia followed, especially in the intralobular ducts adjacent to islets, but a progression to endocrine cells was not seen. When FGF-7 was expressed within the embryonic liver of transgenic mice, driven by an apo E promoter, pancreatic duct hyperplasia was seen, with increased numbers of ductal cells containing immunoreactive insulin (39). The ability of circulating FGF-7 to promote $\beta$-cell neogenesis in the embryo, but only cause ductal cell proliferation in the adult, suggests that additional growth factors, which are only available in early life, are necessary to complete the neogenic process. Overexpression of FGF-7 within the $\beta$-cell population of the fetal mouse using the human insulin promoter caused the appearance of hepatocytes within islets and ducts, suggesting that it may act on uncommitted stem cells (40). We found that immunoreactive FGF-7 was present in the pancreatic mesenchyme and endothelial cells throughout the neonatal period, but was absent from endocrine, exocrine, and ductal epithelial cells. This is in agreement with its expression elsewhere by stromal fibroblasts and other types of mesenchymal cells (41). As in other tissues (42), pancreas contained a single mRNA species encoding FGF-7 of $2.4 \mathrm{~kb}$, which was of greatest abundance between pnd 4 and 12. Although this would correspond to a neonatal increase in ductal epithelial cell proliferation, FGF-7 may also support the ongoing proliferation of $\beta$ cells. We found that exogenous FGF-7 was an extremely potent inducer of islet cell DNA synthesis, being effective at concentrations fivefold lower than either FGF-1 or -2 .
We also examined the presence of FGF-4 and -6 in pancreas, inasmuch as both have been implicated in embryonic morphogenesis fetal tissue maturation, particularly of the musculoskeletal system $(43,44)$. Both were widespread within islets and pancreatic ductal epithelium. Whereas homologous disruption of the FGF-6 gene in mice has no obvious phenotype (45), the abilities of FGF-1, $-2,-4$, and -6 to initiate mitogenic signaling via the FGFR4 receptor, which is abundant in developing pancreas (12), suggests a substantial cooperativity of action, and consequently functional redundancy if one ligand is absent. This would be supported by the presence of all of these ligands within fetal and neonatal islets and duct cells. In contrast, FGF-7 signaling is exclusively via an alternatively spliced product of the FGFR2 gene that will also bind FGF-1 but not FGF-2 (41). Each of the FGFR1 to FGFR4 genes are expressed within pancreas, although their individual cellular ontogeny is not clear (46). A specificity of FGF ligand presentation to receptor species can also be determined by local variation in the structures of heparan sulfate proteoglycans (47). These are necessary for optimal coupling of ligand and receptor.

In summary, we have found that multiple FGF species are present in rat pancreatic ductal epithelium and in developing islets and surrounding mesenchyme in late fetal and neonatal life at a time when substantial remodeling of the endocrine pancreas takes place. They are especially widespread at pnd 12-14 when a wave of ductal cell proliferation and endocrine cell neogenesis is thought to take place.

Acknowledgments. The authors thank the Medical Research Council of Canada, the Canadian Diabetes Association, and the Juvenile Diabetes Foundation International for their financial support. We also thank Dr. Andrew Baird (Ciblex Corporation, San Diego, CA, U.S.A.) for providing us with FGF-2 antibody and hFGF-2 cDNA; Dr. C.V.E. Wright (Vanderbilt University, Nashville, TN, U.S.A.) for supply of the Pdx-1 antibody; and Mr. Stephen Coukell for his technical assistance. We acknowledge the technical assistance of Ms. Cathie Crukley and Mr. Doug Geddes, Department of Pathology, St. Joseph's Health Center, for immunohistochemistry for cytokeratins.

\section{REFERENCES}

1. Duvillie B, Cordonnier C, Deltour L, Dandoy-Dron F, Itier JM, Monthioux E, Jami J, Joshi RL, Bucchini D 1997 Phenotypic alterations in insulin deficient mutant mice. Proc Natl Acad Sci U S A 94:5137-5140

2. Stoffers DA, Zinkin FT, Stanojevik V, Clarke WL, Habener JF 1997 Pancreatic agenesis attributable to a single deletion in the human IPF-1 coding region. Nat Genet 15:106-110

3. Howard CP, Go VL, Infante AJ, Perrault J, Gerich JE, Haymond MW 1980 Long-term survival in a case of functional pancreatic agenesis. J Pediatr 97:786-789

4. Van Assche FA, De Prins F, Aerts L, Verjans M 1977 The endocrine pancreas in small-for-dates infants. Br J Obstet Gynaecol 84:751-753

5. Petrik J, Reusens B, Arany E, Remacle C, Hoet JJ, Hill DJ 1999 A low protein diet alters the balance of islet cell replication and apoptosis in the fetal and neonatal rat, and is associated with a reduced pancreatic expression of insulin-like growth factor-II. Endocrinology 140:4861-4873

6. Barker DJP 1994 The fetal origins of adult disease. Fetal Matern Med Rev 6:71-80

7. Baird A, Bohlen P 1990 Fibroblast growth factors. In: Sporn MB, Roberts AB (eds) Peptide Growth Factors and Their Receptors. Spring-Verlag, Berlin, pp 369-418

8. Beattie GM, Lappi DA, Baird A, Hayek A 1990 Selective elimination of fibroblasts from pancreatic islet monolayers by basic fibroblast growth factor-saporin mitotoxin. Diabetes 39:1002-1005

9. Gonzalez AM, Hill DJ, Logan A, Maher PAA, Baird A 1996 Distribution of fibroblast growth factor (FGF-2) and FGF receptor-1 messenger RNA expression and protein presence in the mid trimester human fetus. Pediatr Res 39:375-385 
10. Gonzalez AM, Buscaglia M, Ong M, Baird A 1990 Distribution of basic fibroblast growth factor in 18-day rat fetus: localization in the basement membranes of diverse tissues. J Cell Biol 110:753-765

11. Oberg-Welsh C, Welsh M 1996 Effects of certain growth factors on in vitro maturation of rat fetal islet-like structures. Pancreas 12:334-339

12. Le Bras S, Miralles F, Basmaciogullari A, Czernichow P, Scharfmann R 1998 Fibroblast growth factor 2 promotes pancreatic epithelial cell proliferation via functional fibroblast growth factor receptors during embryonic life. Diabetes 47:12361242

13. Teitelman G 1991 Cellular and molecular analysis of pancreatic cell lineage and differentiation. In: Bardin CW (ed) Rec Prog Horm Res, San Diego, Academic Press, pp 259-294

14. Teitelman G 1993 On the origin of the pancreatic endocrine cells, proliferation and neoplastic transformation. Tumor Biol 14:167-173

15. Hill DJ, Hogg J 1991 Growth factor control of pancreatic $\beta$ cell hyperplasia. In: Herington A (ed) Clin Endocrinol Metab. Balliere Tindall, London, pp 689-698

16. Kaung HL 1994 Growth dynamics of pancreatic islet cell populations during fetal and neonatal development of the rat. Dev Dyn 200:63-175

17. Hellerstrom C, Swenne I, Andersson A 1988 Islet cell replication and diabetes. In: Lefabvre PJ, Pipeleers DG (eds) The Pathology of the Endocrine Pancreas in Diabetes. Springer-Verlag, Heidelberg, pp 141-170

18. Scaglia L, Cahill CJ, Finegood DT, Bonner-Weir S 1997 Apoptosis participates in the remodeling of the endocrine pancreas in the neonatal rat. Endocrinology 138:17361741

19. Petrik J, Arany E, McDonald TJ, Hill DJ 1998 Apoptosis in the pancreatic islet cells of the neonatal rat is associated with a reduced expression of insulin-like growth factor II that may act as a survival factor. Endocrinology 139:2994-3004

20. Hogg J, Hill DJ, Han VKM 1994 The ontogeny of insulin-like growth factor (IGF) and IGF binding protein gene expression in the rat pancreas. J Mol Endocrinol 13:49-58

21. Hsu SM, Raine L, Fanger H 1981 Use of avidin-biotin peroxidase complex (ABC) in immunoperoxidase techniques: a comparison between $\mathrm{ABC}$ and unlabelled antibody (PAP) procedures. J Histochem Cytochem 29:577-580

22. Arany E, Hill DJ 1998 Fibroblast growth factor-2 and fibroblast growth facto receptor-1 mRNA expression and peptide localization in placentae from normal and diabetic pregnancies. Placenta 19:133-143

23. Wang JF, Milosveski V, Schramek C, Fong GH, Becks GP, Hill DJ 1998 Presence and possible role of vascular endothelial growth factor (VEGF) in thyroid cell growth and function. J Endocrinol 157:5-12

24. Shain SA, Saric T, Ke LD, Nannen D, Yoas S 1996 Endogenous fibroblast growth factor-1 or fibroblast growth factor-2 modulate prostate cancer. Cell Prolif Growth Differ 7:573-583

25. Leung H, Mehta P, Gray L, Collins AT, Robson CN, Neal DE 1997 Keratinocyte growth factor expression in hormone insensitive prostate cancer. Oncogene 15:11151120

26. Hellerstrom C, Lewis NJ, Borg H, Johnson R, Freinkel N 1979 Method for large scale isolation of pancreatic islets by tissue culture of fetal rat pancreas. Diabetes 28:769776

27. Hogg J, Han VKM, Clemmons DR, Hill DJ 1993 Interactions of glucose, insulin-like growth factors (IGFs) and IGF binding proteins in the regulation of DNA synthesis by isolated fetal rat islets of Langerhans. J Endocrinol 138:401-412

28. Finegood DT, Scaglia L, Bonner-Weir S 1995 Dynamics of $\beta$ cell mass in the growing rat pancreas. Diabetes 44:249-256

29. Habener JF, Stoffers DA 1998 A newly discovered role of transcription factors involved in pancreas development and the pathogenesis of diabetes mellitus. Proc Assoc Am Physicians 110:12-21
30. Kornmann M, Beger HG, Korc M 1998 Role of fibroblast growth factors and their receptors in pancreatic cancer and chronic pancreatitis. Pancreas 17:169-175

31. Yamamoto M, Sasaki H, Iseki S 1995 The occurrence of acidic fibroblast growth factor-like immunoreactivity in subpopulations of endocrine cells in the pancreas and intestine of the rat. Arch Histol Cytol 58:475-484

32. Petrik J, Pell JM, Arany E, McDonald TJ, Dean WL, Reik W, Hill DJ 1999 Overexpression of insulin-like growth factor-II in transgenic mice is associated with pancreatic islet cell hyperplasia. Endocrinology 140:2353-2363

33. Lajas AI, Pozo MJ, Salido GM, Pariente JA 1998 Effect of basic fibroblast growth factor on cholecystokinin-induced amylase release and intracellular calcium increase in male rat pancreatic acinar cells. Biochem Pharmacol 55:903-908

34. Thomas D, Groux Muscatelli B, Raes MB, Caruelle JP, Stehelin D, Barritault D, Boilly B 1991 Developmental changes in acidic fibroblast growth factor (aFGF) transcription and expression in mouse brain. Brain Res Dev Brain Res 59:117-122

35. Baldin V, Roman A-M, Bosc-Bierne I, Amalric F, Bouche G 1990 Translocation of bFGF to the nucleus is $G_{1}$ phase cell cycle specific in bovine aortic endothelial cells. EMBO J 9:1511-1517

36. Chotani MA, Chiu IM 1997 Differential regulation of human fibroblast growth factor 1 transcripts provides a mechanism of cell-specific growth factor expression. Cell Growth Differ 8:999-1013

37. Guo L, Degenstein L, Fuchs E 1996 Keratinocyte growth factor is required for hair development but not for wound healing. Genes Dev 10:165-175

38. Yi ES, Yin S, Harclerode DL, Bedoya A, Bikhazi NB, Housley RM, Aukerman SL, Morris CF, Pierce GF, Ulich TR 1994 Keratinocyte growth factor induces pancreatic ductal epithelial proliferation. Am J Pathol 145:80-85

39. Nguyen HQ, Danilenko DM, Bucay N, DeRose ML, Van GY, Thomason A, Simonet WS 1996 Expression of keratinocyte growth factor in embryonic liver of transgenic mice causes changes in epithelial growth and differentiation resulting in polycystic kidneys and other organ malformations. Oncogene 12:2109-2119

40. Krakowski ML, Kritzik MR, Jones EM, Krahl T, Lee J, Arnush M, Gu D, Sarvetnick N 1999 Pancreatic expression of keratinocyte growth factor leads to differentiation of islet hepatocytes and proliferation of duct cells. Am J Pathol 154:683-691

41. Rubin JS, Bottaro DP, Chedid M, Miki T, Ron D, Cunha GR, Finch PW 1995 Keratinocyte growth factor as a cytokine that mediates mesenchymal-epithelial interaction. EXS 74:191-214

42. Leung HY, Mehta P, Gray LB, Collins AT, Robson CN, Neal DE 1997 Keratinocyte growth factor expression in hormone insensitive prostate cancer. Oncogene 15:11151120

43. Laufer E, Nelson CE, Johnson RL, Morgan BA, Tabin C 1994 Sonic hedgehog and Fgf-4 act through a signaling cascade and feedback loop to integrate growth and patterning of the developing limb bud. Cell 79:993-1003

44. Coulier F, Pizette S, Ollendorff V, deLapeyriere O, Birnbaum D 1994 The human and mouse fibroblast growth factor 6 (FGF6) genes and their products: possible implication in muscle development. Prog Growth Factor Res 5:1-14

45. Fiore F, Planche J, Gibier P, Sebille A, deLapeyriere O, Birnbaum D 1997 Apparent normal phenotype of FGF6-/- mice. Int J Dev Biol 41:639-642

46. Partanen J, Makela TP, Eerola E, Korhonen J, Hirvonen H, Claesson-Welsh L, Alitalo K 1991 FGFR-4, a novel acidic fibroblast growth factor receptor with a distinct expression pattern. EMBO J 10:1347-1354

47. Ishihara M 1994 Structural requirements in heparin for binding and activation of FGF-1 and FGF-4 are different from that for FGF-2. Glycobiology 4:817-824 